\title{
IMPEDANCE SPECTROSCOPY ANALYSIS OF A LIQUID TIN ANODE FUEL CELL IN VOLTAGE RECOVERY MODE
}

\author{
${ }^{1}$ Prattana Kaewpet and ${ }^{2}$ Klaus Hellgardt \\ ${ }^{1}$ Department of Electrical Engineering, Faculty of Engineering, \\ King Mongkut's Institute of Technology Ladkrabang, Chalongkrung 1 Road, \\ Ladkrabang,Bangkok, Thailand. 10520. \\ ${ }^{2}$ REaCT Group, Department of Chemical Engineering and Chemical Technology, \\ Imperial College London. SW7 2AZ.
}

\begin{abstract}
A concept of a liquid tin anode-indirect carbon air fuel cell (LTA-ICFC) are described. Experimental setups for analysis of LTA-ICFC polarisations of an operational electrochemical reactor of the LTA-ICFC are presented. Results from Electrochemical Impedance Spectroscopy (EIS) Analysis of the electrochemical reactor of the LTA-ICFC are shown and analysed.The rate-determining step of the system is concluded. The charge-transfer resistance did not show considerable differences at 700-800 ${ }^{\circ} \mathrm{C}$. This can be implied that the charge-transfer resistance is not the rate-limiting step of the transport processes of the fuel cell. The increase of the Warburg impedance concurrently with the resistance to fit mass-transport loss (R3) suggests that the rate-limiting step for the LTA-ICFC in voltage recovery mode is the diffusion of the oxide ions through $\mathrm{SnO}_{2}$ layer. The increment of mass transport lost, $\mathrm{R} 3$, of the cell causes the slowly increase of the cell's voltage over the voltage from 0.7-0.8 $\mathrm{V}$ at 700, 750, and $800^{\circ} \mathrm{C}$.
\end{abstract}

\section{Keywords}

Liquid tin anode fuel cell, Impedance spectroscopy analysis, Polarisation losses

\section{INTRODUCTION}

An alternative energy conversion technology, such as fuel cell technology, offers many attractive possibilities for reducing both, air pollution and the unselective consumption of precious chemicals. High temperature fuel cells convert the chemical energy of a fuel into electrical energy due to its high temperatures of operation with high efficiency and much lower emission levels than any other energy conversion system. They can also provide many other advantages over tradition energy conversion system including reliability, modularity, fuel adaptability, and no need for an expensive, external reformer. Furthermore, some fuel cell types such as high temperature solid oxide fuel cells (SOFCs), if coupled with gas turbine to work as combustors, such hybrid SOFCs gas turbine power systems can be expected to reach efficiencies higher than $70 \%[1]$.

The concept of a carbon/air fuel cell is based on direct carbon conversion. The process is similar to that of a hydrogen fuel cell but differs in using carbon instead of hydrogen as a fuel. The fuel, carbon, would be in form of fine particulates $(\sim 100 \mathrm{~nm})$ to facilitate mass transfer. Carbon would be distributed by entrainment in a flow of $\mathrm{CO}_{2}$ to the cell to form, for example, slurry of carbon in a melt - the melt being the anode of the fuel cell [2]. Because the carbon/air fuel cell sustains the

DOI : 10.5121/aeij.2016.3301 
reaction, $\mathrm{C}+\mathrm{O}_{2}=\mathrm{CO}_{2}$, a pure stream of $\mathrm{CO}_{2}$ would emerge. This would lead to facile sequestration of $\mathrm{CO}_{2}$ without additional collection and separation costs.

Nevertheless, the concept of an indirect carbon-air fuel cell, patented by Imperial College London, has been proposed [3]. The overall aim of this project is to demonstrate the feasibility and development of this type of fuel cell. The concept of Liquid Tin Anode 'Indirect' Carbon-Air Fuel Cell (LTA-ICFC) is presented in Figure 1. Figure 1 demonstrates a schematic of the fuel cell coupled to 'ex-cell' combustion reactor in which carbonaceous particles are oxidised to $\mathrm{CO}_{2}$ by dissolved oxygen in molten metal. The key challenges that have been received significant attentions comprise: minimisation of Ohmic losses: design and construction of reactor and electrolyte: anode-reactor and anode-electrolyte interaction: and prevailing polarisation losses in the operational fuel cells.

The core aim of the research is dedicated to the electrochemical reactor. In this paper, the study of the electrochemical processes occurring in the fuel cell from obtained electrochemical data from impedance spectroscopy is presented. To extract model parameters from impedance spectra, electrochemical software that provides common Equivalent Circuit Models was used.

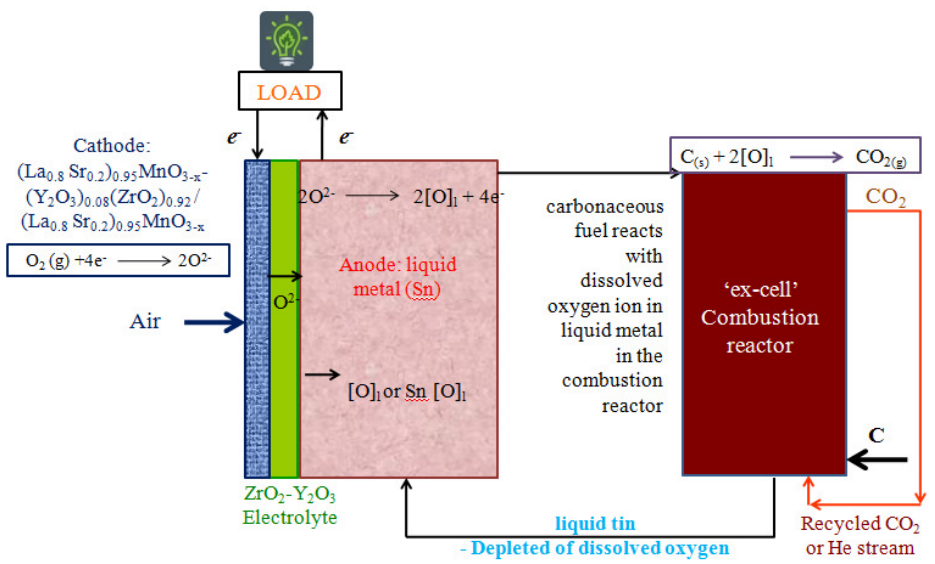

Figure 1: LTA-ICFC schematic diagram [3]

\section{EXPERIMENTAL DATA}

2.1 The experimental set up used to study current density effect on time dependent growth of $\mathrm{SnO}_{2}$

In Figure 2,the fuel cell set up comprises closed-one-end tubular YSZ electrolyte $\left(10 \mathrm{~mol} \% \mathrm{Y}_{2} \mathrm{O}_{3}\right.$, McDanel, USA) with a $6.35 \mathrm{~mm}$ outside and $4.78 \mathrm{~mm}$ inside diameter with a $3.05 \mathrm{~mm}$ diameter graphite rod current collector (Alfa Aesar, UK), and approximately $4 \mathrm{~kg}$ of analytical grade tin ( $>99.99$ wt\%, Merck Chemicals Ltd.). Both Alumina crucible (fuel cell supporter) and alumina tubing were purchased from Almath Crucibles Ltd., UK with diameter of $80 \mathrm{~mm}$ and $\sim 3 \mathrm{~mm}$ outside diameter, respectively. Cathode materials are LSM/YSZ and LSM as well as ink vehicle were purchased from Fuel Cell Material.com, USA.

\subsection{Experimental process steps}

1) After completion of typical OCV measurements and cell performance test of cell 1 (working fuel cell) and cell 2 (reference fuel cell), cell1 was connected to an assigned load and cell 2 was kept under no load condition. This experimental work was set with different conditions for both 
cells in order to determine the resistive changes as results of formation and dissolution of $\mathrm{SnO}_{2}$ as a function of time at the liquid tin/YSZ interface at cell 1 . While cell 1 was being investigated changes under load, cell 2 was also synchronously measured OCV to monitor the oxygen concentration changes in the liquid tin.

2) The fuel cell was assembled and closed. Then the furnace temperature controller was programmed to the working temperatures from $700-800{ }^{\circ} \mathrm{C}$. The heating/cooling rates were controlled at lower than $3^{\circ} \mathrm{C} / \mathrm{min}$ in order to avoid cracking of the ceramics as a result of temperature gradients.

3) After reaching the melting point of tin $\left(232.1^{\circ} \mathrm{C}\right)$, He and Air valves were switched on and Air valve was kept open until the end of the experiment. For impedance measurements, He valve was closed prior to the measurements. The air flow fed to the cathode was set at $10 \mathrm{ml} / \mathrm{min}$. Two alumina tubes were used for inlet gas delivery into the anode chamber. OCV of the cell was monitored and recorded at a constant temperature and gas flow rate.

4) The fuel cell was connected to a Metroohm Autolab Potentiostat for impedance spectroscopy measurements to obtain the initial series resistance of the cell using NOVA 1.7 software to record the data.

5) A constant resistance was set at the resistance box and then connected to the cell1 at both electrodes. The data were monitored and recorded through the Agilent multi-meters with USB connectors to a computer. Each experiment was conducted for longer than 15 hours to ascertain that the oxygen ions/tin oxide layer accumulation at the liquid tin/YSZ electrolyte interface was stable. This step was done in order to study the effect of current density drawn from the fuel cell to the rate of formation/ dissolution the tin-oxide layer that was expected to affect the resistive changes of the working fuel cell.

6) A second electrolyte was used to monitor the change of oxygen solubility in the liquid tin bulk when current is drawn from the cell1 This second electrolyte, so called cell 2, was an important means to independently determine the actual oxygen concentration (using OCV values) in the liquid tin anode in order to compare to the voltages of the cell1.

7) After 15 hours, the working fuel cell was disconnected from the resistance box and immediately was conducted the impedance measurements. The impedance spectra were recorded every 10-30 minutes until the cell's voltage stepped back to the OCV or considerably close.

8) i-V or polarization measurements were carried out thereafter and recorded as the cells' performance after long operation.

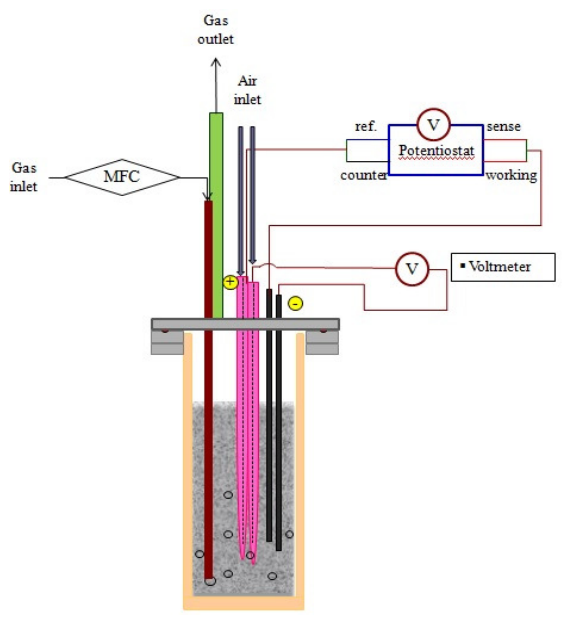


Figure 2: Schematically diagram of experimental set up for impedance spectroscopy

The impedance spectra obtained after the cell1 was disconnected from an external circuit with a resistance of $10 \Omega$ at $700-800^{\circ} \mathrm{C}$ are presented in Figures 3-5, respectively. While the voltage of the cell1 were recovering to its OCV, an impedance spectra was collected approximately every 10-30 minutes depending on the progress of the cell1's voltage. Toward the end of the impedance measurements at each temperature, the voltage of cell 1 increased fairly slowly, the impedance measurements were therefore collected at longer intervals.

\section{RESULTS AND DISCUSSION}

\subsection{Electrochemical Impedance Spectroscopy (EIS) in voltage recovering mode}

Impedance measurements of the fuel cell were carried out periodically after the fuel cell was disconnected from an external load resistor. Impedance spectra were measured in potentiostatic mode in the frequency range of $0.1-100 \mathrm{kHz}$, with the current range of $100 \mathrm{~mA}$ and amplitude of $10 \mathrm{mV}$ (rms). Nyquist plots of the impedance spectra of the fuel cell at $700-800{ }^{\circ} \mathrm{C}$ are presented in Figures 3-5, respectively. The changes in impedance spectra in Figures 3 are presumed to be associated with the anodic reactions/ processes since the $\mathrm{pO}_{2}$ in the cathode input stream was kept constant at 0.21 atm (air). Therefore the changes of the impedance spectra measured after a complete cycle given in Figure 3 corresponded to the changes of the anode side i.e. the formation of a $\mathrm{SnO}_{2}$ layer at the surface of the YSZ electrolyte, according to the oxidation of Sn, Eq. (1):

$$
\mathrm{Sn}+2 \mathrm{O}^{2-} \leftrightarrow \mathrm{SnO}_{2}+4 \mathrm{e}^{-}(1)
$$

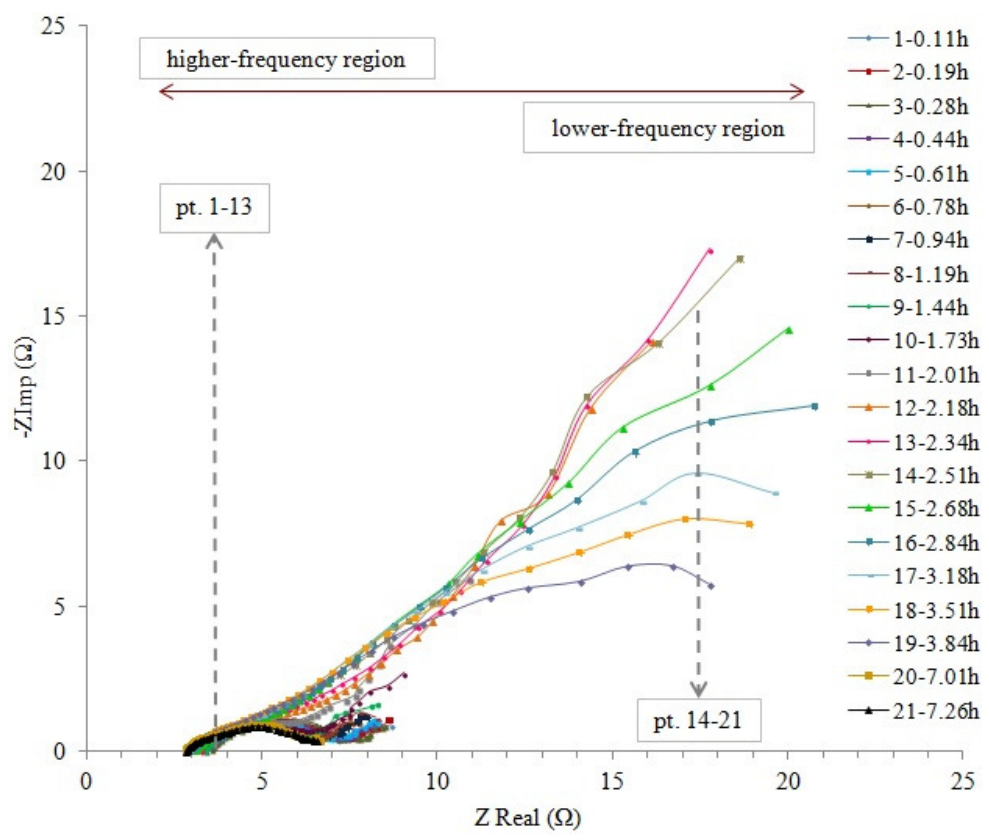

Figure 3: Impedance spectra of cell 1 at $700{ }^{\circ} \mathrm{C}$ after disconnecting the external load 


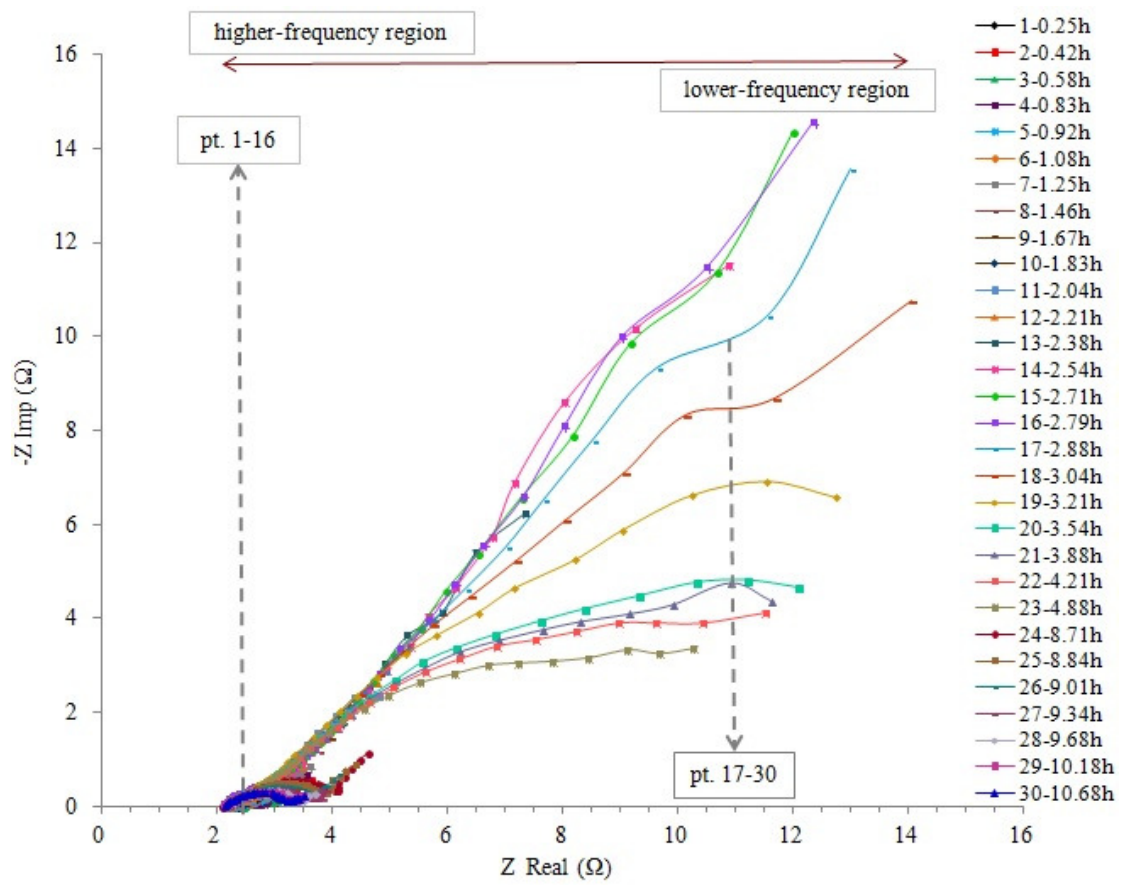

Figure 4: Impedance spectra of cell 1 at $750{ }^{\circ} \mathrm{C}$ after disconnecting the external load

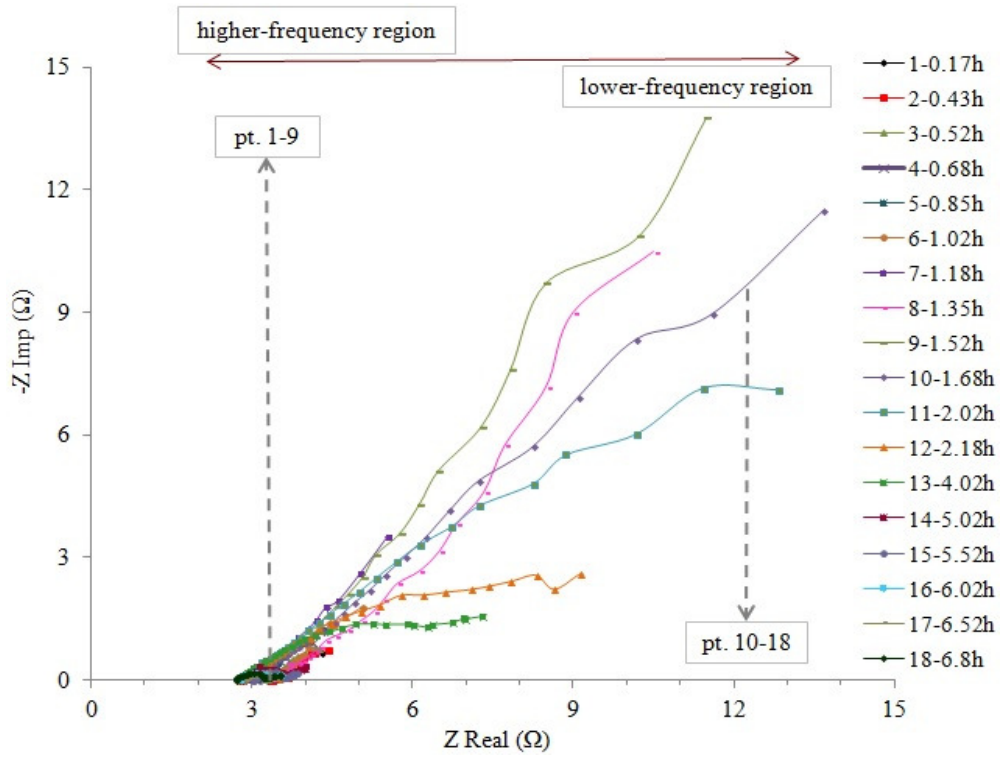

Figure 5: Impedance spectra of cell 1 at $800{ }^{\circ} \mathrm{C}$ after disconnecting the external load

Figures 4-5 also demonstrate impedance spectra obtained from the cell1 after the polarisation test was done at 750 and $800{ }^{\circ} \mathrm{C}$. After completion of a polarisation experiment, the external load was unconnected, and the impedance spectra of cell1 were instantly measured and recorded 
periodically as same as at $700^{\circ} \mathrm{C}$ at every 10 mins at the first few hours and then every $20-30$ mins depending on the extent of the change of the cell voltage.

Small semicircles can be observed in the high-frequency range and the Warburg impedance can be seen in low-frequency range as a $45^{\circ}$ line or less in the set of the impedance spectra. After 30 mins of measurement the spectra show that the diffusion polarisation was dominated. Whilst the cell voltage ascending back to just below its OCV, the impedance spectra eventually became semicircle loops again with a smaller Warburg impedance. Since the diffusion polarization, to some extent, affected the developing characterization of cell voltage, the Warburg impedance of each spectra at different conditions were analysed using the Electrochemical Impedance Analyser (EIS) software. The calculated diffusion coefficients derived from the Warburg impedance from all measuring temperatures are subsequently presented as a function of time, in the EIS analysis section.

\subsection{EIS Analysis}

The "best-fitted" equivalent circuit for the impedance spectra in Figures 3-5 is depicted in Figure6. Figure 6 shows the corresponding equivalent circuit model for the LTA-ICFC obtained from EIS Spectrum Analyser. The circuit is composed of a series combination of: (1) an inductance, (2) an ohmic resistance, (3) a parallel combinations of a constant phase element (CPE) and a resistance, and (4) a parallel combination of a CPE, and a resistance and Warburg impedance. The equivalent circuit is thus symbolised as L1R1(R2Q1)([R3W1]Q), where Q represents the CPE.

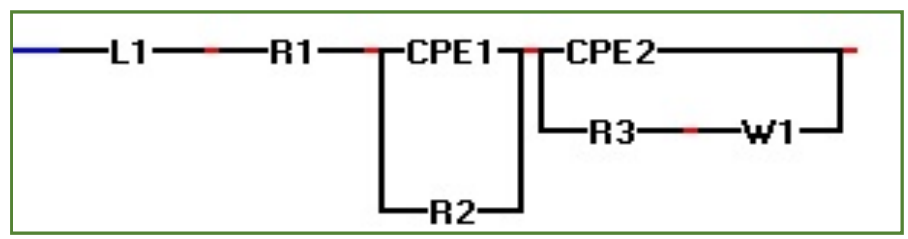

Figure 6: Corresponding equivalent circuit model for LTA-ICFC provided from EIS Spectrum Analyser

The equivalent model comprises 7 components: L1, R1, R2, R3, CPE1, CPE2, and W1. The meanings of these elements are as follow:

(1) L1, inductance resulted from instrument

(2) R1, resistor to fit ionic loss that is mainly evolved from the resistance of the electrolyte

(3) R2, resistor to fit the kinetic loss or charge transfer resistance

(4) R3, resistor to fit mass transport loss

(5) CPE1 constant phase elements to fit the relaxation time of charge-transfer process

(6) CPE2, constant phase elements to fit the relaxation time of diffusion process and

(7) W1, the Warburg impedance, created by the diffusion of the oxide ions through $\mathrm{SnO}_{2}$ and liquid tin anode.

The deconvoluted impedance parameters were obtained by fitting the data displayed in each line of the Nyquist plots in Figures 3-5 in the EIS analyser. All parameters are listed in Tables 1-3. In Tables 1-3, there are various dependent variables of each individual Equivalent element in the circuit. These variables can be explained as follows:

- $\mathrm{Y}_{0,1}$ and $\mathrm{Y}_{0,2}$ are the capacitance of CPE1 and CPE2, respectively

- $\mathrm{n}_{1}$ and $\mathrm{n}_{2}$ are $\mathrm{n}$-value of the capacitance of CPE1 and CPE2, respectively. 
Advanced Energy: An International Journal (AEIJ), Vol. 3, No. 2/3, July 2016

- $\mathrm{A}_{\mathrm{w}}$ is the Warburg coefficient of W1

Table 1:The deconvoluted impedance parameters acquired at $700{ }^{\circ} \mathrm{C}$

\begin{tabular}{|l|l|l|l|l|l|l|l|l|l|l|}
\hline Point & $\begin{array}{l}\text { Voltag } \\
\mathrm{e}[\mathrm{V}]\end{array}$ & $\mathrm{R} 1$ & $\mathrm{R} 2$ & $\mathrm{R} 3$ & $\mathrm{~A}_{\mathrm{w}}$ & $\mathrm{Y}_{0,1}$ & $\mathrm{n}_{1}$ & $\mathrm{Y}_{0,2}$ & $\mathrm{n}_{2}$ & L1 \\
\hline 1 & 0.04 & 3.3 & 2.7 & 1.3 & 0.8 & 0.01 & 0.5 & 0.004 & 0.7 & $3 \mathrm{E}-06$ \\
\hline 2 & 0.04 & 3.2 & 3.0 & 1.3 & 0.8 & 0.01 & 0.5 & 0.002 & 0.8 & $3 \mathrm{E}-06$ \\
\hline 3 & 0.05 & 3.1 & 3.3 & 1.6 & 4.0 & 0.00 & 0.7 & 0.350 & 0.2 & $3 \mathrm{E}-06$ \\
\hline 4 & 0.06 & 3.3 & 2.0 & 1.9 & 0.9 & 0.00 & 0.6 & 0.002 & 0.7 & $3 \mathrm{E}-06$ \\
\hline 5 & 0.08 & 3.2 & 2.0 & 2.0 & 1.0 & 0.00 & 0.7 & 0.020 & 0.5 & $3 \mathrm{E}-06$ \\
\hline 6 & 0.09 & 3.0 & 2.0 & 1.6 & 0.9 & 0.02 & 0.4 & 0.002 & 0.7 & $3 \mathrm{E}-06$ \\
\hline 7 & 0.11 & 3.0 & 2.0 & 2.0 & 0.9 & 0.08 & 0.3 & 0.002 & 0.7 & $3 \mathrm{E}-06$ \\
\hline 8 & 0.14 & 3.0 & 2.0 & 2.0 & 1.3 & 0.00 & 0.7 & 0.070 & 0.4 & $3 \mathrm{E}-06$ \\
\hline 9 & 0.21 & 3.0 & 1.7 & 1.6 & 1.5 & 0.00 & 0.7 & 0.030 & 0.4 & $3 \mathrm{E}-06$ \\
\hline 10 & 0.48 & 3.0 & 2.0 & 1.2 & 2.1 & 0.01 & 0.7 & 0.003 & 0.7 & $3 \mathrm{E}-06$ \\
\hline 11 & 0.72 & 2.9 & 3.3 & 3.0 & 5.7 & 0.01 & 0.6 & 0.090 & 0.8 & $3 \mathrm{E}-07$ \\
\hline 12 & 0.74 & 2.9 & 4.6 & 33.5 & 52.8 & 0.01 & 0.5 & 0.080 & 0.7 & $3 \mathrm{E}-06$ \\
\hline 13 & 0.74 & 3.0 & 4.8 & 12.0 & 27.0 & 0.02 & 0.5 & 0.050 & 0.8 & $3 \mathrm{E}-06$ \\
\hline 14 & 0.76 & 3.0 & 2.4 & 8.0 & 21.4 & 0.01 & 0.6 & 0.040 & 0.7 & $3 \mathrm{E}-06$ \\
\hline 15 & 0.77 & 3.0 & 1.7 & 8.0 & 23.0 & 0.01 & 0.7 & 0.040 & 0.6 & $3 \mathrm{E}-06$ \\
\hline 16 & 0.77 & 2.8 & 4.0 & 14.0 & 8.6 & 0.02 & 0.5 & 0.040 & 0.8 & $3 \mathrm{E}-06$ \\
\hline 17 & 0.78 & 2.8 & 3.0 & 20.0 & 4.8 & 0.01 & 0.6 & 0.045 & 0.7 & $3 \mathrm{E}-06$ \\
\hline 18 & 0.79 & 2.7 & 3.9 & 16.0 & 3.0 & 0.02 & 0.5 & 0.050 & 0.8 & $3 \mathrm{E}-06$ \\
\hline 19 & 0.80 & 2.7 & 2.0 & 1.6 & 0.3 & 0.01 & 0.5 & 0.030 & 0.8 & $3 \mathrm{E}-06$ \\
\hline 20 & 0.94 & 2.7 & 2.0 & 1.4 & 0.4 & 0.01 & 0.5 & 0.020 & 0.9 & $3 \mathrm{E}-06$ \\
\hline 21 & 0.94 & 2.6 & 2.3 & 1.2 & 0.4 & 0.02 & 0.5 & 0.020 & 0.9 & $3 \mathrm{E}-06$ \\
\hline
\end{tabular}

Table 2:The deconvoluted impedance parameters acquired at $750{ }^{\circ} \mathrm{C}$

\begin{tabular}{|c|c|c|c|c|c|c|c|c|c|c|}
\hline Point & $\begin{array}{l}\text { Voltag } \\
\text { e [V] }\end{array}$ & $\mathrm{R} 1$ & $\mathrm{R} 2$ & R3 & $\mathrm{A}_{\mathrm{w}}$ & $\mathrm{Y}_{0,1}$ & $\mathrm{n}_{1}$ & $\mathrm{Y}_{0,2}$ & $\mathrm{n}_{2}$ & L1 \\
\hline 1 & 0.11 & 2.0 & 0.2 & 0.3 & 0.5 & 0.03 & 0.7 & 0.06 & 0.4 & $3 \mathrm{E}-06$ \\
\hline 2 & 0.14 & 2.0 & 0.7 & 0.5 & 0.5 & 0.00 & 0.6 & 0.07 & 0.4 & $1 \mathrm{E}-05$ \\
\hline 3 & 0.20 & 2.0 & 0.5 & 0.3 & 0.7 & 0.00 & 0.7 & 0.40 & 0.5 & 9E-06 \\
\hline 4 & 0.47 & 2.0 & 0.3 & 0.3 & 0.7 & 0.01 & 0.8 & 0.40 & 0.6 & $4 \mathrm{E}-06$ \\
\hline 5 & 0.57 & 2.0 & 0.3 & 0.8 & 1.0 & 0.02 & 0.7 & 0.65 & 0.6 & $3 \mathrm{E}-06$ \\
\hline 6 & 0.65 & 2.0 & 0.4 & 0.8 & 0.8 & 0.01 & 0.7 & 0.60 & 0.7 & $4 \mathrm{E}-06$ \\
\hline 7 & 0.68 & 2.0 & 0.4 & 1.0 & 0.9 & 0.02 & 0.7 & 0.60 & 0.7 & $2 \mathrm{E}-06$ \\
\hline 8 & 0.71 & 2.0 & 0.4 & 0.7 & 1.0 & 0.01 & 0.7 & 0.40 & 0.8 & $3 \mathrm{E}-06$ \\
\hline 9 & 0.73 & 2.1 & 0.3 & 1.5 & 3.0 & 0.01 & 0.7 & 0.50 & 0.6 & $3 \mathrm{E}-06$ \\
\hline 10 & 0.74 & 2.1 & 0.7 & 1.6 & 1.6 & 0.10 & 0.4 & 0.40 & 0.4 & $3 \mathrm{E}-06$ \\
\hline 11 & 0.76 & 2.0 & 0.7 & 0.6 & 3.0 & 0.10 & 0.4 & 0.20 & 0.8 & $3 \mathrm{E}-06$ \\
\hline 12 & 0.80 & 2.0 & 0.7 & 0.6 & 3.8 & 0.04 & 0.5 & 0.10 & 0.8 & $3 \mathrm{E}-06$ \\
\hline 13 & 0.85 & 2.0 & 0.8 & 1.0 & 11.0 & 0.10 & 0.4 & 0.10 & 0.7 & $3 \mathrm{E}-06$ \\
\hline 14 & 0.87 & 2.0 & 1.0 & 5.0 & 30.0 & 0.02 & 0.5 & 0.07 & 0.7 & $5 \mathrm{E}-06$ \\
\hline 15 & 0.88 & 1.9 & 1.6 & 10.0 & 29.0 & 0.06 & 0.4 & 0.08 & 0.7 & 5E-06 \\
\hline 16 & 0.89 & 2.0 & 4.0 & 12.0 & 20.0 & 0.10 & 0.4 & 0.07 & 0.8 & $3 \mathrm{E}-06$ \\
\hline 17 & 0.89 & 2.0 & 2.0 & 5.0 & 13.0 & 0.07 & 0.4 & 0.05 & 0.8 & $3 \mathrm{E}-06$ \\
\hline 18 & 0.89 & 2.0 & 6.0 & 9.4 & 6.7 & 0.14 & 0.4 & 0.07 & 0.9 & 3E-05 \\
\hline 19 & 0.90 & 2.0 & 5.0 & 1.0 & 5.0 & 0.10 & 0.8 & 0.01 & 0.6 & $6 \mathrm{E}-06$ \\
\hline 20 & 0.90 & 2.0 & 5.0 & 1.0 & 4.0 & 0.10 & 0.8 & 0.02 & 0.5 & $6 \mathrm{E}-06$ \\
\hline 21 & 0.91 & 2.0 & 5.0 & 1.0 & 3.4 & 0.07 & 0.8 & 0.02 & 0.5 & $6 \mathrm{E}-06$ \\
\hline 22 & 0.91 & 2.0 & 5.0 & 1.4 & 3.0 & 0.07 & 0.9 & 0.04 & 0.5 & $6 \mathrm{E}-06$ \\
\hline 23 & 0.91 & 2.0 & 5.0 & 0.8 & 2.0 & 0.07 & 0.8 & 0.01 & 0.6 & $7 \mathrm{E}-06$ \\
\hline 24 & 0.91 & 2.0 & 1.0 & 0.9 & 0.8 & 0.03 & 0.8 & 0.05 & 0.5 & $3 \mathrm{E}-06$ \\
\hline 25 & 0.91 & 2.0 & 0.9 & 0.8 & 0.7 & 0.03 & 0.8 & 0.06 & 0.4 & $3 \mathrm{E}-06$ \\
\hline 26 & 0.91 & 2.0 & 0.8 & 0.8 & 0.4 & 0.04 & 0.8 & 0.03 & 0.5 & $6 \mathrm{E}-06$ \\
\hline
\end{tabular}


Advanced Energy: An International Journal (AEIJ), Vol. 3, No. 2/3, July 2016

\begin{tabular}{|l|l|l|l|l|l|l|l|l|l|l|}
\hline 27 & 0.91 & 2.0 & 0.7 & 0.8 & 0.3 & 0.03 & 0.8 & 0.01 & 0.6 & $6 \mathrm{E}-06$ \\
\hline 28 & 0.91 & 2.0 & 0.7 & 0.6 & 0.2 & 0.03 & 0.5 & 0.03 & 0.8 & $3 \mathrm{E}-06$ \\
\hline 29 & 0.91 & 2.0 & 0.9 & 0.5 & 0.1 & 0.03 & 0.7 & 0.10 & 0.4 & $3 \mathrm{E}-06$ \\
\hline 30 & 0.91 & 2.0 & 0.7 & 0.6 & 0.1 & 0.08 & 0.5 & 0.09 & 0.5 & $3 \mathrm{E}-06$ \\
\hline
\end{tabular}

Table 3:The deconvoluted impedance parameters acquired at $800{ }^{\circ} \mathrm{C}$

\begin{tabular}{|l|l|l|l|l|l|l|l|l|l|l|}
\hline Point & $\begin{array}{l}\text { Voltag } \\
\text { e [V] }\end{array}$ & $\mathrm{R} 1$ & $\mathrm{R} 2$ & $\mathrm{R} 3$ & $\mathrm{~A}_{\mathrm{w}}$ & $\mathrm{Y}_{0,1}$ & $\mathrm{n}_{1}$ & $\mathrm{Y}_{0,2}$ & $\mathrm{n}_{2}$ & L1 \\
\hline 1 & 0.03 & 3.2 & 0.2 & 2.6 & 0.4 & 0.70 & 0.2 & 0.80 & 0.6 & 4E-06 \\
\hline 2 & 0.07 & 3.3 & 0.3 & 2.2 & 0.6 & 0.10 & 0.7 & 1.00 & 0.7 & $8 \mathrm{E}-06$ \\
\hline 3 & 0.08 & 3.2 & 0.4 & 1.4 & 0.2 & 0.50 & 0.5 & 1.00 & 1.0 & $3 \mathrm{E}-06$ \\
\hline 4 & 0.13 & 3.0 & 0.6 & 1.3 & 0.3 & 0.60 & 0.5 & 1.00 & 1.0 & $3 \mathrm{E}-06$ \\
\hline 5 & 0.19 & 2.9 & 0.9 & 1.5 & 0.5 & 0.50 & 0.4 & 0.80 & 1.0 & 4E-06 \\
\hline 6 & 0.46 & 3.4 & 0.6 & 1.8 & 1.1 & 0.30 & 0.6 & 0.50 & 1.0 & 4E-06 \\
\hline 7 & 0.60 & 2.9 & 1.1 & 2.1 & 2.7 & 0.20 & 0.6 & 0.30 & 1.0 & 4E-06 \\
\hline 8 & 0.62 & 3.3 & 1.5 & 3.0 & 11.7 & 0.05 & 0.6 & 0.07 & 0.9 & $5 \mathrm{E}-06$ \\
\hline 9 & 0.65 & 2.7 & 2.4 & 3.8 & 28.0 & 0.10 & 0.4 & 0.07 & 0.8 & 4E-06 \\
\hline 10 & 0.66 & 2.9 & 5.0 & 8.0 & 7.4 & 0.08 & 0.5 & 0.08 & 1.0 & $3 \mathrm{E}-06$ \\
\hline 11 & 0.68 & 2.6 & 6.2 & 9.0 & 3.3 & 0.10 & 0.4 & 0.10 & 0.9 & 4E-06 \\
\hline 12 & 0.68 & 2.7 & 5.3 & 3.0 & 0.9 & 0.20 & 0.4 & 0.10 & 0.8 & 4E-06 \\
\hline 13 & 0.73 & 2.7 & 2.5 & 2.0 & 0.8 & 0.10 & 0.5 & 0.10 & 0.8 & $1 \mathrm{E}-06$ \\
\hline 14 & 0.79 & 2.0 & 1.0 & 0.6 & 0.3 & 0.02 & 0.3 & 0.02 & 0.8 & 5E-06 \\
\hline 15 & 0.87 & 2.3 & 1.0 & 0.3 & 0.2 & 0.04 & 0.2 & 0.04 & 0.8 & 4E-06 \\
\hline 16 & 0.88 & 2.4 & 1.0 & 0.3 & 0.2 & 0.06 & 0.2 & 0.02 & 0.9 & 4E-06 \\
\hline 17 & 0.89 & 2.4 & 0.6 & 0.3 & 0.2 & 0.10 & 0.2 & 0.02 & 0.8 & 4E-06 \\
\hline 18 & 0.89 & 2.5 & 0.3 & 0.5 & 0.2 & 0.26 & 0.2 & 0.02 & 0.7 & $3 \mathrm{E}-06$ \\
\hline
\end{tabular}

It is likely that the inductance is the results of $\sim 40-50 \mathrm{~cm}$ of unshielded $\mathrm{Ag}$ wire and wool that is used as lead to the cathode. The average inductance of apparatus at 700,750 , and $800{ }^{\circ} \mathrm{C}$ are $3 \mathrm{E}^{-6}$, $5.5 \mathrm{E}^{-6}$, and $4 \mathrm{E}^{-6}$ Henry, respectively, which are probably varied due to the variation of the length of $\mathrm{Ag}$ wire and the amount of $\mathrm{Ag}$ wool used. The relationship between the inductance of an inductor and the length and/or number of turns of the material used can be expressed in the following equation:

$$
\mathrm{L}=\frac{\mu_{0} \mu_{\mathrm{r}} \mathrm{N}^{2} \mathrm{~A}}{\mathrm{l}}(2)[6]
$$

where $\mathrm{L}$ is the inductance in henries $(\mathrm{H}), \mu 0$ is permeability of free space $=4 \pi . \mathrm{E}-07 \mathrm{H} \cdot \mathrm{m}-1, \mu \mathrm{r}$ is relative permeability of core material, $\mathrm{N}$ is number of turns/number of wire wraps, $\mathrm{A}$ is area of cross-section of the coil in square metres $(\mathrm{m} 2)$, and 1 is the length of the coil in metres $(\mathrm{m})$. In addition to the dimensions of the coil (Ag wire) used, coil area (as measured at the cross-section of the core and core material (which is, in this case, SS316) factors can also affect the inductance created [7]. But since the SS316 with 1/8" o.d. was always used as the core, these latter factors were then ignored. Unlike inductance of a conductor material, the resistance seems to be more influenced with operational temperatures; for example: silver's temperature coefficient is 0.0038 $\Omega .{ }^{\circ} \mathrm{C}-1$ [6]. Therefore, temperature may not be expected to affect the inductance as much as the resistance of the cell.

From the results in Tables 1-3, the R1 component is assigned to the ohmic resistance. The parallel combination of R2Q1that appears as a semi-circle at the high-frequency region is ascribed to the kinetic or charge transfer resistance, based on the fact that R2decreased when the operating temperature was raised. This is because the kinetics of $\mathrm{O}_{2}$ reduction is faster at higher temperature [8].The ohmic loss in this cell at $700-800{ }^{\circ} \mathrm{C}$ were higher than expected from the $\mathrm{R}_{\mathrm{YsZ}}$ values for the $1.6 \mathrm{~mm}$ electrolyte $\left(0.36,0.23\right.$, and $0.16 \Omega$ at $700-800{ }^{\circ} \mathrm{C}$, respectively), possibly due to poor electrical connections of the silver lead wire and wool. Impedance data presented previously 
demonstrated that the ohmic resistance of the cell remained unchanged after completing the polarization test but the non-ohmic resistance increased dramatically (as can be seen at the impedance spectra measured while the cell voltage was recovering to its $\mathrm{OCV}$ ), because of the barrier to diffusion of the oxide ions from the electrolyte.

Additionally, the R2Q1 component is also controlled by the charge-transfer process at the YSZ/LTA since the CPE component in this region is dependent on oxygen pressure but the oxygen pressure was kept constant at $0.21 \mathrm{~atm}$, Therefore, the changes of R2 and CPE1 are due to the magnitude of $\mathrm{SnO}_{2}$, and the $\mathrm{O}^{2-}$ to travel across the LTA-YSZ interface and then react with liquid tin.As the first combination of the circuit elements is attributed to the charge transfer resistance, the second combination of circuit elements is attributed to the presence of mass transport losses, while the $45^{\circ}$ line (i.e. Warburg element) is due to the ion diffusion through the $\mathrm{SnO}_{2}$ layer and liquid tin anode.

The results in Tables 1-3 illustrate that $\mathrm{R} 1$ is invariant with the measured recovery time in comparison to R2 and R3 which show significant variations in line with the relative changes of the cell voltage after removal of the load at $700-800{ }^{\circ} \mathrm{C}$. All the resistances R1, R2, and R3 decreased when the temperature increased. However, R1 at $750{ }^{\circ} \mathrm{C}$ appear to be close to that of at $800^{\circ} \mathrm{C}$, which can be explained as a result of poor electronic connection of the lead wire.

A resistance, R2, is caused by a single kinetically controlled electrochemical reaction Eq. (3). Considering the liquid tin in contact with the YSZ electrolyte the 2O2- transferred across the YSZ electrochemically dissolve into the liquid tin forming $\mathrm{SnO} 2$ or $\mathrm{Sn}[\mathrm{O}] 2(\mathrm{l})$ and $4 \mathrm{e}$ - charge is being transferred. The charge transfer reaction has a certain rate. The rate depends on the kind of reaction, the temperature, the concentration of the reaction products and the potential [9].

When the overpotential, $\eta$, is very small and the electrochemical system is at equilibrium, the express for the charge transfer resistance is given as shown in Eq. (3):

$$
\mathrm{R}_{\mathrm{ct}}=\frac{\mathrm{RT}}{\mathrm{nFi}_{0}}
$$

where $R_{c t}$ is the charge-transfer resistance, which is equivalent to $R_{c t}, R$ is molar gas constant, $T$ is absolute temperature, $\mathrm{n}$ is the number of electron involved in the reaction, and $\mathrm{i}_{0}$ is the exchange current. Extracting from the model, $\mathrm{R} 2$ or $\mathrm{R}_{\mathrm{ct}}$, can be used to calculate the exchange current density for cell 1 at $700-800{ }^{\circ} \mathrm{C}$. The exchange current at different conditions are calculated and plotted in Figure 7 showing the highest value at $800^{\circ} \mathrm{C}$.

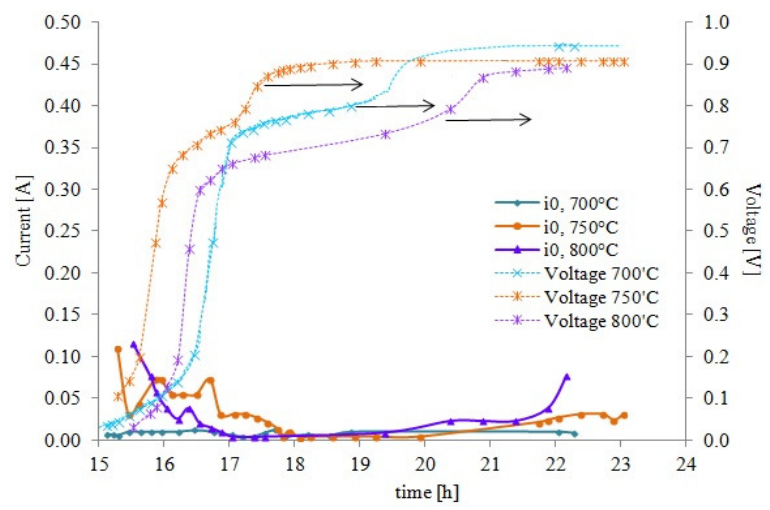

Figure 7: The exchange current/ideally current density calculated from $\mathrm{R}_{\mathrm{ct}}$ at $700-800{ }^{\circ} \mathrm{C}$ 
The mass transport resistances at different temperatures, R3, show a slower increasing rate as the cell voltage rising. It is clearly seen that the mass transport resistance is the major cause for slowing down fuel cell's recovering voltage when the fuel cell is operating in the battery mode.

The formed $\mathrm{SnO}_{2}$ layer is assumed to be the barrier for charge-transfer processes and a cause of the mass transport loss. It is useful to estimate the thickness of the $\mathrm{SnO}_{2}$ or $\mathrm{Sn}\left[\mathrm{O}_{(1)}\right]_{\mathrm{x}}$ film as a function of time at each temperature by calculating the capacitance, $\mathrm{Y}_{0,2}$, obtained from the model. Since the tin-oxide, $\mathrm{SnO}_{2}$, is assigned as the reaction product formed as a dielectric layer at YSZ/liquid tin interface, $\mathrm{Y}_{0.2}$ or the capacitance, $\mathrm{C}$, of CPE2 can be considered the capacitance of the dielectric layer. The equation for capacitance of the oxide film is then given as:

$$
\mathrm{C}=\frac{\varepsilon \varepsilon_{0} \mathrm{~S}}{\mathrm{~d}}
$$

where $\mathrm{C}$ is the capacitance $=\mathrm{Y}_{0,2}$ listed in Tables 1-3,

$\varepsilon_{0}$ is permittivity of free space (NIST calls it simply the "electric constant") $=8.854 \mathrm{E}^{-12} \mathrm{~F}^{-\mathrm{m}^{-1}}[10]$, $\varepsilon_{\mathrm{r}}$ is dielectric constant (relative electrical permittivity) $=12.5[-][11]$,

A is surface of the YSZ electrolyte $=23.14 \mathrm{~cm}^{2}$, and $\mathrm{d}$ is the thickness of $\mathrm{SnO}_{2}$ layer to be calculated.

A support for this assignment is further provided by the $\mathrm{n}$ values of $\mathrm{Q} 2$ which are close to unity $[9,12](>0.75)$ where the impedance spectra contain $\sim 45^{\circ}$ contours. The $\mathrm{SnO}_{2}$, like many other oxide phases which have no activity for oxygen reduction behaves like an ideal capacitor to give an $n$ value of unity [12].

When the $\mathrm{SnO}_{2}$ film was formed, the capacitance of the fuel cell coincidently evolved. The capacitance of the oxide film is one part of the capacitance in the system. Apart from that, the space charge regions (between $\mathrm{SnO}_{\mathrm{x}}$ and the liquid tin/tin ions) where the $\mathrm{SnO}_{2}$ dissociates can also be considered as another part of the capacitance, i.e. $Y_{o}$ of CPE1. But only the capacitance of CPE2 in the proposed equivalent circuit can be used to calculate the estimated thickness of the oxide layer. The results in Tables 1-3 show that the capacitance is higher at higher temperature [13], which could be expected since the oxygen solubility at $800{ }^{\circ} \mathrm{C}$ is higher than at 700 and 750 ${ }^{\circ} \mathrm{C}$ leading to thinner layers of tin oxide.

\subsection{Analysis of the Warburg impedance (W1) from the impedance spectra}

After approximately 0.5 hour of disconnecting from the resistor, the impedance spectra show the clear presence of a Warburg impedance, which corresponds to the diffusion of oxide ions diffusing through the $\mathrm{SnO}_{2}$ layer. Impedance created by diffusion is called Warburg impedance, which is dependent on the frequency of the potential perturbation. The Warburg-impedance at low frequencies is higher than at high-frequencies because the reactants have to diffuse farther [9]. In the LTA-ICFC, the Warburg-impedance could be a result of the diffusion of oxide ions through YSZ/LTA interface and tin oxide layer.

The equation for "infinite" Warburg impedance is $[9,15]$ :

$$
\mathrm{Z}_{\mathrm{W}}=\sigma \omega^{-\frac{1}{2}}(1-\mathrm{j})(5)
$$

in which $\omega$ is radial frequency, $\sigma$ is the Warburg coefficient obtainable from fitting the impedance spectra to the equivalent circuit, Ohm. $\mathrm{s}^{-0.5}$. In the EIS analyser used the $\sigma$ is represented as $\mathrm{A}_{\mathrm{W}}$. 
The general expression of the Warburg element and its impedance can also be written as

$$
\mathrm{Z}_{\mathrm{W}}=\sigma(\mathrm{i} \omega)^{-\frac{1}{2}}(6)[16]
$$

where

$$
\sigma=\frac{\mathrm{RT}}{\mathrm{n}^{2} \mathrm{~F}^{2} \mathrm{~A}} \cdot \frac{1}{\mathrm{C}_{\mathrm{O}} \sqrt{\mathrm{D}}}(7)[16]
$$

$\mathrm{C}_{\mathrm{O}}$ and Do represent the oxygen solubility and diffusion coefficient of the oxide ions, $\mathrm{A}$ is the electrode area, $\mathrm{n}$ is the number of electrons in involved in the reaction, $\mathrm{F}$ is Faraday constant , and $\mathrm{R}$ is molar gas constant, and $\mathrm{T}$ is absolute temperature.

Using, the Warburg coefficient, $A_{W}(\sigma$ in Eq. (6)), obtained from fitting the impedance spectra to the equivalent circuit for W1 (given in Tables 1-3), and Do calculated from [4] and [14], $C_{O}$ can be computed from Eq. (7). The $\mathrm{C}_{O}$ results are then compared to maximum oxygen solubility in the liquid tin re-calculated from at $\% \mathrm{O}$ or $\mathrm{wt} \% \mathrm{O}$ provided in literature[5]. The results of $\mathrm{C}_{\mathrm{O}}$ that applied 2 different $D_{0}$ from 2 different references $[4,14]$ are presented in Figure 8 as a function of temperature.

Because the oxygen solubility in liquid tin at higher temperature is higher, the solubility at $800{ }^{\circ} \mathrm{C}$ is expected to have the highest value. By using the $A_{w}$ (Warburg coefficient), obtained from fitting the W1 element in the proposed equivalent circuit, to calculate the actual oxygen concentration in the tin, the calculated oxygen concentrations presented as a function of temperature from $700-800{ }^{\circ} \mathrm{C}$ are displayed in Figure 8.

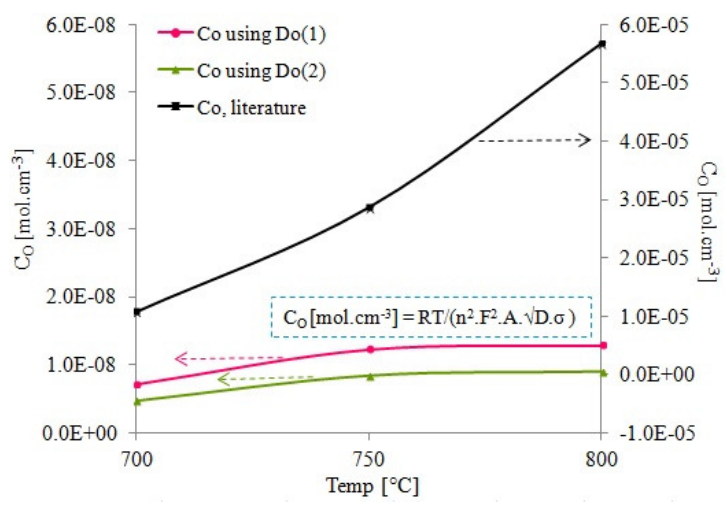

Figure 8: Oxygen concentration calculated from Eq. (7) plotted as a function of temperature using Aw $(\sigma)$ from EIS fitting and $D_{O}$ values calculated from [4] and [14], respectively

The actual minimum concentration of tin oxide/oxygen ions (where the $A_{W}$ is highest) in liquid tin that was detected at 700,750 and $800{ }^{\circ} \mathrm{C}$ are $4.8-7.2 \mathrm{E}^{-9}, 8.4 \mathrm{E}^{-9}-1.2 \mathrm{E}^{-8}, 9 \mathrm{E}^{-9}-1.3 \mathrm{E}^{-8}$ mol.cm ${ }^{-3}$, respectively. This confirms that operating the LTA-ICFC at higher temperature is more suitable to prevent the formation of $\mathrm{SnO}_{2}$ that causes the higher mass transport loss. Not only is the mass transport resistance decreased by operating at higher temperature, but the ionic resistances also shows lower values leading to better performance of the cell. 
Advanced Energy: An International Journal (AEIJ), Vol. 3, No. 2/3, July 2016

\section{CONCLUSIONS}

Electrochemical Impedance Spectroscopy (EIS) analyser was used to determine the deconvoluted impedance parameters acquired at 700,750 and $800{ }^{\circ} \mathrm{C}$ which had been the lacking data for analysis of this type of fuel cells. Also, the average ohmic resistance and the maximum overall resistance of the LTA-ICFC were acquired at the elevated temperatures in this work. Even though the stage of recovering voltage of the fuel cell was found to be sluggish at the plateau/shoulder regions, from the EIS fitting, it was significantly discovered by the authors that mass transportrelated loss is the major loss of the fuel cell in battery mode. If a fuel is used in order to reduce the oxide products the plateau regions of fuel cell voltage in recovering stage should not exist.The increase of the Warburg impedance concurrently with the resistance to fit mass-transport loss (R3) suggests that the rate-limiting step for the LTA-ICFC in voltage recovery mode is the diffusion of the oxide ions through $\mathrm{SnO}_{2}$ layer. The increment of mass transport lost, $\mathrm{R} 3$, of the cell causes the slowly increase of the cell's voltage over the voltage from 0.7-0.8 V at 700, 750, and $800{ }^{\circ} \mathrm{C}$. The charge-transfer resistance did not show considerable different values in the range of $700-800{ }^{\circ} \mathrm{C}$ as compared to other research work which conducted experiments using other types of fuel cells. This can be implied that the charge-transfer resistance is not the rate-limiting step of the transport processes of the liquid tin anode fuel cell.

\section{ACKNOWLEDGEMENTS}

The authors wish to show grateful thanks to the Royal Thai Government and the Office of the Higher Education Commission, Thailand, for financial support for this work.

\section{REFERENCES}

1. S.C. Singhal, (2000). Advances in solid oxide fuel cell technology. Solid State Ionics, 135, 305313.

2. W. Ron, (2004) Direct carbon fuel cells: Assessment of their potential as solid carbon fuel based power generation systems. Lawrence Livermore National Laboratory. Report number: UCRL-SR203880.

3. Klaus, H. and Geoff, K. (2008). Indirect Carbon-Air Fuel Cells. London. Patent Fuel Cells No. P40713GB.

4. T.A. Ramanarayanan, and R.A. Rapp, (1972). The Diffusivity and Solubility of Oxygen in Liquid Tin and Solid Silver and the Diffusivity of Oxygen in Solid Nickel. METALLURGICAL TRANSACTIONS, 3: 3239-3246.

5. A. Jayakumar, S. Lee, A. Hornes, J.M. Vohs, and R.J. Gorte, (2010). A comparison of Molten Sn and Bi for Solid Oxide Fuel Cell Anodes. J. of Electrochemical Society, 157(3): B365-B369.

6. DfR Solutions, White Paper. Uprating of Magnetic Components: INDUCTORS, FERRITE BEADS AND TRANSFORMERS. Maryland

7. DESIGN SCIENCE LICENSE. (2012). Factors affecting inductance. [Online] Available from: http://www.allaboutcircuits.com/vol_1/chpt_15/3.html [Accessed 26th July 2013].

8. X.J. Chen, K.A. Khor, and S.H. Chan, (2003) Identification of O2 reduction processes at yttria stabilized zirconia/doped lanthanum manganite interface. J. of Power Sources. 123: 17-25.

9. GAMRY Instrument. (2013). Application Note: Basics of Electrochemical Impedance Spectroscopy. Copyright 1990-2009 Gamry Instruments, Inc.

10. A.B. Shabbir, (1998). Study of Indium Tin Oxide (ITO) for Novel Optoelectronic Devices. (Thesis). KING'S COLLEGE LONDON. University of London. Department of Electronic Engineering.

11. H.J.V. Dall, (1968). The Static Dielectric Constant of SnO2. J. Appl. Phys., 39: 4467-2269.

12. S.S. Hwa, H.K. Wi, H.H., Sang, M. Jooho, K. Joosun, and L. Hae-Weon, (2007). Effect of starting particulate materials on microstructure and cathodic performance of nanoporous LSM/YSZ composite cathodes. J. of Power Sources., 167: 258-264. 
13. A.S. Lanje, S. J. Sharma, R.B. Pode, and, R.S. Ningthoujam, (2010). Dielectric study of Tin oxide nanoparticles at low temperature. Arch. Apll. Sci. Res., 2 (2): 127-135.

14. O. Shinya, K. Zensaku, and Y.C. Austin, (1984). Oxygen Solubility in Liquid Indium and Oxygen Diffusivity in Liquid Indium and Tin. METALLURGICAL TRANSACTION B., 15B: 329-335.

15. V. Daria, (2013) “a, b, c" Impedance. Centre of Excellence "Portable and Emergency Energy Sources”. Bulgaria.

16. J.V. Herle, and A.J. McEvov, (1993). O2 diffusion through silver cathodes for Solid Oxide Fuel Cells. J. Phys. Chem., 55 (4): 339-347.

\section{Corresponding Author}

2014 Diploma of the Imperial College (DIC), PhD of Imperial College London, Chemical Engineering and Chemical Technology Research. Thesis Title: Design and Operation of a Novel Carbon/Air Fuel Cell Reaction and Catalytic Technology Research Group (REaCT)

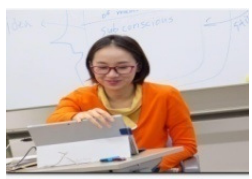

2007 M.S. Industrial Chemistry Chiang Mai University, Thailand. (Grade 3.93/4.0 Graduate Student, 1st Rank Award Winner, and 1st class honor) Thesis Title: Adsorbent Preparation from the Pyrolysis of Tea Leaf Residues

Energy Fuel and Petrochemical Research Unit

2005 B.S. Industrial Chemistry Chiang Mai University, Thailand. (Grade 3.42/4.0 Upper Second Class Honors) Final Report Project Title: Briquetting of Coal Combined with Biomass Binder

Energy Fuel and Petrochemical Research Unit 